\title{
George W. Bush and the Reckoning of American Conservatism
}

\author{
Leonard J. Moore
}

Immediately after the 2004 election, Republicans confidently believed in continued conservative political dominance. Shortly, a string of political and administrative disasters shattered the Bush presidency, and crises yet to come further devastated the political fortunes of American conservatism. Bush's failures as president, while highly significant, only partially explained the conservative collapse. The deeper cause lay in the long term weakness of conservative policies and political tactics. An examination of two key aspects of modern conservatism, conservative populism and opposition to government activism, shows that the collapse came primarily because of Bush's loyalty to entrenched, mainstream conservative ideas and policies that were unrealistic and destined to fail.

On November 5, 2004, the day after being elected to a second term as president, George W. Bush held a press conference to assess his re-election victory and his plans for the next four years. Much of the discussion focused on Iraq. In tones upbeat and resolute, he insisted, as he had throughout the presidential campaign, that the invasion of Iraq had been a necessary step in the war against terrorism and that significant progress was being made toward the establishment of a free, democratic government. Evidence of that progress, he said, could be seen in the parliamentary elections scheduled to take place in January 2005. In response to a question about how the war had harmed the international reputation of the United States, particularly in the Islamic world, Bush observed, "There is a certain attitude in the world, by some, that says that it's a waste of time to promote free societies in parts of the world." Such a view, he declared, was "just not part of my thinking." He made a brief reference to the buildup for a long anticipated second offensive in Fallujah, stressing its importance for maintaining security in the upcoming elections. On domestic matters, Bush underscored his plans to reform Social Security, bringing it more in line with his larger goal of achieving what he called an ownership society. He brushed aside a question about the possibility that his policies disproportionately favored large corporations and the wealthy, claiming that his tax cuts had greatly benefited small business. When asked to reflect on his personal response to winning a second term in light of his father's defeat in 1992 and the controversy that surrounded the

LEONARD J. MOORE is an associate professor of history at McGill University.

The American Review of Politics, Vol. 29, Winter, 2008-2009: 291-309

(C)2008 The American Review of Politics 
2000 election, he uttered one of the memorable and, as it turned out, supremely ironic lines of his presidency. "I earned capital in the campaign," he said, "political capital, and now I intend to spend it." (Bush 2004).

Much of the initial election analysis appeared to justify the President's optimistic mood. At first glance it seemed he had won primarily by tapping deep into a die-hard base of conservative voters - church-going inhabitants of rural communities, suburbs, and exurbs who had turned out to vote in particularly significant numbers. Whether they were "values" voters motivated by opposition to gay marriage or abortion, or whether they simply admired the President's plain-spoken confidence, his Christian faith, or his unwavering views on national security, it seemed plausible to conclude that they were an important part of what Bush's chief political strategist, Karl Rove, along with other excited conservative voices, were calling a permanent Republican majority.

Bush's triumphal second inaugural address in January was both a bold neoconservative proclamation of America's world mission and a brash, at times, curious conflation of limited government conservatism and interventionist progressivism. America's international calling, Bush asserted, had a clear context and led to unambiguous choices. "For half a century," he declared, "America defended our own freedom by standing watch on distant borders." After the collapse of communism there had been "years of repose, years of sabbatical," until eventually, "there came a day of fire." Now, in the wake of the September 11 attack, the United States had a responsibility to "expose the pretensions of tyrants, and reward the hopes of the decent and tolerant." The United States, he promised, "will not impose our own style of government on the unwilling," and "America's influence is not unlimited, but fortunately for the oppressed, America's influence is considerable, and we will use it confidently in freedom's cause.” After these and other muscular warnings to "every ruler and every nation," Bush turned his attention to the "unfinished work of American freedom" at home. Other generations, he pointed out, had expanded freedom by overcoming slavery, preserving the Union and fighting for civil rights. They had campaigned for "the dignity and security of economic independence," by advancing legislation such as the Homestead Act, the Social Security Act, and the G.I. Bill. Now, he said, he intended to extend that tradition by widening "the ownership of homes and businesses, retirement savings and health insurance, preparing our people for the challenges of life in a free society." Supported by communities and a national culture that sustained timeless moral values based on religion, American self government could come to rely, "in the end, on the governing of the self." "In America's ideal of freedom," he said, "the public interest depends on private character." With un-cited allusions to Franklin Roosevelt's Four Freedoms and Martin Luther King, Jr.'s famous 
declaration that the arc of the moral universe is long but bends toward justice, Bush fused his conservative vision with past campaigns for security and equality. "By making every citizen an agent of his or her own destiny, we will give our fellow Americans greater freedom from want and fear ..." he said. "History has an ebb and flow of justice," he proclaimed, "but history also has a visible direction” (Bush 2005).

Bush's moment of triumph, of course, was short-lived. The second battle of Fallujah, which began four days after the November election, involved ten days of brutal street fighting, the worst of its kind for U.S. Marine and Army forces since Vietnam; building-by-building mop-up operations lasted for months afterward. It would achieve little in the larger struggle against metastasizing insurgencies and bloody civil strife in Iraq. The gruesome situation continued month after month-despite the parliamentary elections-with the primary architect of the catastrophe, Secretary of Defense Donald Rumsfeld, remaining on the job and the President seemingly in deep denial (Gordon and Trainor 2006; Ricks 2006).

Other debacles soon followed. Bush's legislative agenda ran aground when Congress summarily rejected his plan for partial privatization of the Social Security system. Another embarrassment occurred at roughly the same time when Bush and the Republican Congress lent full support in March to a ludicrous campaign by right-wing religious groups to intervene in the family tragedy surrounding Terry Schiavo (Eisenberg 2005). The indictment of lobbyist Jack Abramoff in August exposed extraordinary levels of ruthlessness, corruption, and cronyism in the world of Republican fund raising and corporate lobbying. Conservative icon Tom DeLay was indicted for violating Texas election law in September 2005 and lost his leadership position in the Republican Congress; the following April he would resign from Congress altogether. Hurricane Katrina, which struck the Gulf Coast near New Orleans on August 29, mortally wounded Bush's public image. The President reacted to the crisis in a way that suggested he was out of touch and perhaps unable fully to grasp the nature and extent of the damage and human suffering involved. His administration showed itself to be grossly incompetent in dealing with the disaster (Horne 2006; van Heerden and Bryan 2006). Just weeks after Katrina, I. Lewis "Scooter" Libby was indicted for obstruction of justice in the Valerie Plame affair. Libby, Vice President Dick Cheney's Chief of Staff, would later be convicted, only to have the President commute his thirty-month prison sentence, the entire episode further stigmatizing Bush and his administration as dishonest and contemptuous of the law. Less than a year after his reelection, Bush's public approval ratings sank to the lowest level for any president since the advent of polling. 
All of this occurred before Republican losses in the 2006 midterm election; before further revelations of incompetence and abuse of power led to resignations by Donald Rumsfeld, Karl Rove, Alberto Gonzales, and other key players in the Bush administration; and before the home mortgage and Wall Street disasters plunged the nation into the worst economic crisis since the Great Depression.

Amid the wreckage of the Bush presidency, it is easy to forget the Republicans' triumphal mood in late 2004, early 2005. Indeed, the swaggering confidence of that time and the President's ambitious plans to advance conservative policies already seem like part of a past political era, or simply like chamber music on the Titanic. Bush will forever be known first and foremost for his catastrophic failures, not his victories. He will be seen, with a great deal of justification, as the person who presided over the stunning collapse of the conservative ascendancy of the last four decades, the political era many are already calling, in retrospect, the Age of Reagan (Wilentz 2008).

The Republicans' confidence in the wake of winning a second Bush term, however, is well worth remembering. Bush's reelection, it must be remembered, was no fluke. He did indeed draw on a devoted and powerful political base that had been created over decades of hard and deliberate political work, and he was able to reach out successfully, as had other conservative leaders before him, to attract sufficient support from moderates and independents. The ideas and policies espoused by Bush as he campaigned for reelection were those of the conservative mainstream, not some extreme fringe element. He was only the fourth of eleven post-World War II presidents to serve two full terms. He was a mainstream conservative, not a radical, and his reelection-along with the triumphal mood it engenderedunderscored the continuity between his presidency and the main currents of the conservative ascendancy itself.

The Republicans' bravado of 2004-2005 is significant also because it called attention to one of the major, long-term weaknesses of the conservative ascendancy: the vast gulf between the hard-sell political marketing of conservative ideology and the actual social, economic, and political conditions in American life. Bush's poor relationship with "reality based” politics was stamped all over his vision of conservatism triumphant. He actually had very little political capital to crow about in November 2004 (even though on this occasion, unlike 2000, he had at least won the popular vote). His margin of victory over John Kerry was razor thin, boiling down to a difference of approximately 119, 000 votes in Ohio, where, as in Florida in 2000, there would be serious, legitimate questions raised about election fraud and vote suppression (Freeman and Bleifuss 2006). The Republicans did control Congress, but partisan polarization remained intense and Bush could expect 
fervent opposition to any ideologically conservative initiative, particularly one involving Social Security. Even more salient than a Congress and an electorate divided was the fact that Bush was already carrying the burden of great policy failures. Highly regressive tax cuts had resulted in massive new federal deficits and underscored the deep and growing problems of economic inequality in American society. Iraq had already blown up in the nation's face. The campaign against the Taliban and Al Qaeda in Afghanistan had been left unfinished. And tragically, Bush had failed to take advantage of the passionate national consensus in the wake of September 11 to address the many critical issues tied to energy consumption. In the real post2004 election world, the idea of a mandate was an illusion, and the rationale for a permanent Republican majority could not have been more flimsy.

This essay will focus on two key aspects of the conservative ascendancy-its reliance on conservative populism and its opposition to activist government. The primary argument will be that the Bush presidency is best understood for its continuity with, rather than its departure from, the main currents of the conservative ascendancy, and that the conservative ascendancy collapsed primarily as a result of its long-term failures, not simply because of the failed presidency of George W. Bush. The conservative ascendancy was felled not by radicals who went too far to the right, conservative leaders who weren't conservative enough, or by a series of unpredictable disasters, natural or economic. In reality, modern conservatism had always been a heart attack waiting to happen, and during Bush's second term, it did.

The passionate conservative populism that powered the political right and ultimately became its Achilles heel had its modern roots in the watershed era of the civil rights movement. The successful assault on Jim Crow laws during the 1950s and 1960s profoundly reconfigured the meaning of citizenship in the United States, opening the door to a new era of social justice and equality under the law, gradually undermining ancient prejudice and expanding civil, political, economic, and personal freedom. For many Americans, however, the civil rights revolution was perceived as the catalyst for an across-the-board assault on the nation's established values and beliefs, involving not just race and ethnicity, but gender, family, sexuality, religion, science and education, and nation and patriotism, among other issues. From the days of massive resistance to the emergence of George Wallace and Richard Nixon's silent majority, through protracted battles over the administration of justice, busing, school prayer, evolution, personal privacy and abortion, the Equal Rights Amendment, and affirmative action, to 
contemporary conflicts over gay rights, voting rights and the administration of fair elections, conservative populists waged countless successful battles to thwart civil rights reforms, claiming to stand against elites and radicals who threatened majority values. The conservative ascendancy almost certainly owed the majority of its political success, beginning at the presidential level in 1968 and eventually extending to the Congressional, state and local levels, to its ability to mobilize its forces in defense of popular, traditional visions of political and cultural authority (Black and Black 2002; Carter 1995; 1996; Perlstein 2008; Link 2008; Shulman and Zelizer 2008).

And yet, while populist passions helped conservatives win elections, in the long run they came with a huge price tag, both for the Republican Party and the nation. For the nation, the cost came in the form of a decades-long struggle over what might best be understood as a civil rights cold war; or a constant, continually evolving set of conflicts that came in the wake of the great battles in the streets, the courts, and the Congress. The anti-civil rights message was shaped by conservative leaders such as William F. Buckley, George Wallace, Barry Goldwater, Phyllis Schlafly, Ronald Reagan, Jesse Helms, George H.W. Bush, and Richard Nixon, among others, all of whom argued or campaigned against the civil rights movement or politically exploited public opposition to it from the late 1950s through the mid-1960s. From that point forward, conservatives ignited firestorms of cultural conflict as they fought to contain the civil rights revolution. African Americans and Latinos who sought equal voting rights and fair representation in government, an end to discrimination in housing, employment, and other areas, were challenging private property rights, asking for special privileges, and undermining the ideal of a "colorblind" society (Kousser 1999; Keyssar 2000). Supporters of affirmative action were doing the same in the area of employment and education, practicing "reverse discrimination" and subverting the idea that merit should determine individual success (Anderson 2005). School integration programs traumatized the neighborhoods of working class families that couldn't afford to escape to the suburbs or send their children to private schools (Formisano, 1991; Lukas, 1985). Women who sought equal opportunity, challenged traditional assumptions about gender, and demanded the right to shape the course of their private lives, including the ability to use birth control or obtain an abortion, were threatening the institutions of marriage and the family and even undermining the sanctity of life itself (Hull and Hoffer 2001; Critchlow 1999, 2005, 2007). Gays and lesbians seeking equality before the law were attempting to legitimize perversion (Rimmerman, Wald, and Wilcox 2000; Marcus 2002). Americans who believed in the separation of church and state and pressed to keep public schools and other government institutions on a secular footing 
were tearing down the nation's Judeo-Christian heritage and discriminating against people of faith (Dierenfeld 2007; Larson 2003).

Political conflicts over these and other civil rights issues, of course, cannot easily be reduced to a simple story of struggle between the forces of light and darkness. Each took place in the context of changing historical circumstances, each reflected competing democratic visions, complex social and economic conditions, and the magnetic pull of deeply held cultural traditions. Recent scholarship on the issue of race and grassroots conservatism in the modern south, for example, has demonstrated that the historic shift in the political loyalties of white southern voters over the last forty years, in many ways, defies simple explanation (Kruse 2005; Lasiter 2006; Sokol 2006; Crespino 2007). At the same time, however, there can be little doubt that the conservative ascendancy was driven forward by persistent anti-civil rights policies and political campaigns that found endlessly creative ways to stigmatize ongoing concerns for equality and human rights as un-American and threatening. The dismal civil rights records of the Reagan and first and second Bush presidencies are well documented. So, too, are the infamously divisive campaign tactics of the conservative era, including: the launching of Ronald Reagan's 1980 presidential campaign and his pledge to uphold states' rights just outside of Philadelphia, Mississippi, a community made famous by a seminal event of the civil rights movement, the 1964 murders of Michael Schwerner, James Chaney, and Andrew Goodman; George H.W. Bush's notorious campaign in 1988 that aggressively exploited fears of African American criminals, attacked the American Civil Liberties Union as un-American, and whipped up popular opposition to recent Supreme Court decisions concerning the First Amendment, the Pledge of Allegiance and the burning of the American flag; and George W. Bush's 2004 campaign, which pressed for a constitutional amendment banning gay marriage while Republican-sponsored anti-gay rights initiatives in eleven states help stoke the turnout rate of social conservatives (Wilentz 2008; New York Times, November 4, 2004).

The conservative ascendancy also tapped deeply and perhaps most successfully into intense popular disapproval of civil rights decisions by the Supreme Court. From the historic decisions of the Warren Court affecting segregation, voting rights, school prayer, and criminal rights, through later controversial decisions that identified a right of privacy and protected women's ability to obtain birth control or an abortion, to the Bakke decision in 1978 that upheld affirmative action, conservatives targeted the federal courts as agents of a liberal intellectual elite that sought to win in the courts political conflicts it could not win at the ballot box. The battle, of course, had begun with waves of protest against Brown v. Board of Education, the rise of the massive resistance movement, the infamous Southern Manifesto 
in Congress, and the efforts in the early 1960s to impeach Earl Warren. Richard Nixon fused law and order themes with direct attacks on the courts during his 1968 campaign and went on to create intense controversy with attempts to appoint blatantly anti-civil rights justices to the Supreme Court. By the time Reagan won the presidency, opposition to "judicial activism" had become a conservative creed. Reagan, and later George H.W. Bush, took pains to fill the federal bench and every seat on the Supreme Court with men and women who were strict constructionists and generally unsympathetic to the courts' role in the civil rights revolution (Kluger 1976; Tushnet 1994, 1997; Newton 2006; Perlstein 2008). George W. Bush was particularly successful in carrying out the conservative agenda in this regard, winning the appointments of John Roberts and Samuel Alito to the Supreme Court in 2005 and 2006, respectively. While both Reagan and the elder Bush had enjoyed only mixed results in appointing justices to the Supreme Court who would conform to conservative ideology on voting rights, abortion, affirmative action, discrimination in the workplace and other civil rights issues, Chief Justice Roberts and Justice Alito have proven to be consistent conservatives (Washington Post, June 29, 2007).

If decades of conservative populism helped build a Supreme Court generally inhospitable to civil rights causes, it also opened the door to Constitutional abuses that even the Roberts Court could not approve. In the wake of the September 11 attacks, the Bush administration swept up a still unknown number of people off American streets and subjected them to secret confinement and abuse without access to lawyers. It conducted secret surveillance, without warrants, of telephone and internet communication inside the United States, seemingly in direct violation of the Foreign Intelligence Surveillance Act. It engaged in shocking practices of abuse and torture at the detainee camp at Guantánamo Bay, the American prison in Abu Ghraib, elsewhere in Iraq, and in secret locations around the world, all in wanton violation of the Geneva Conventions that an earlier generation of Americans had helped write. These and other activities by the Bush administration not only disgraced the United States in the eyes of the world, they also put into sharp focus the long record of hostility to equality and civil liberties that reigned within the conservative ascendancy. In a series of decisions, the two most important being Hamdan v. Rumsfeld (2006) and Boumediene v. Bush (2008), the Supreme Court strongly rebuked Bush's policies toward Guantánamo detainees, ruling that they were entitled to fair trials and that the United States government was required to honor the Geneva Conventions (Lichtblau 2008; Mayer 2008).

As a result of its record on civil rights, the conservative ascendancy has painted itself into a cultural and demographic corner, spreading a gospel of narrowness and insularity while post-civil rights America has grown ever- 
more diverse and pluralistic. The chasm between the Republican Party and the African American voter is, of course, the most obvious example. Throughout the conservative ascendancy African American voters rejected the Republican Party by a factor of nine to one, or worse, with the conservative record on civil rights playing a large role in determining African American political loyalties. Latino voters demonstrated less solidarity in rejecting the Republican Party, but the majority did so consistently, and during the last decade, as anti-immigrant attitudes have intensified, that majority has grown significantly (Lewis-Beck, Norpoth, Jacoby and Weisberg 2008). The gender gap became one of the hallmarks of the conservative ascendancy. In every presidential election from 1980 forward, women and men divided in their support for Republican and Democratic candidates, with men consistently and significantly surpassing women in favoring Republicans. In a recent assessment of these and other trends in voting behavior, Alan Abramowitz concludes that the Republican base has declined significantly over the last several decades. Younger voters, who accept post-civil rights pluralism as the norm and are more concerned about the economic future than the defense of traditional values, now strongly favor the Democrats. Married white Christians who have made up a vital voting block for the Republicans are declining as a percentage of the electorate, according to Abramowitz (Abramowitz 2008). By 2008, with Democrats nominating an African American for president for the first time in U.S. history, the demographic breakdown of delegates to Republican National Convention captured perfectly the problem of diversity within American conservatism. Ninety-three percent of the delegates were white, sixty-eight percent were male; just five percent were Latino and two percent were African American (New York Times, September 3, 2008).

\section{III}

If conservative populism ultimately isolated conservatism from an increasingly diverse social and cultural mainstream, a second pillar of the conservative ascendancy gradually eroded the ability of the government to perform vital functions and ultimately threatened social and economic disaster.

When Ronald Reagan famously declared in his first inaugural address that "in the present crisis, government is not the solution to our problem; government is the problem," American conservatives had been decrying federal power and the liberal state for more than fifty years. During the 1920s, conservative, pro-business Republicans wrestled control of the party from its progressive wing, became dominant in national politics, and established the basic outline of social and economic policies that conservatives 
would promote in various forms throughout the twentieth century: low taxes for the affluent; limited government intervention in support of social welfare; and aggressive intervention to promote business interests. The Great Depression and the rise of New Deal liberalism, to be sure, pushed economic conservatives to the margins of public policy debates and Republicans to a minority status in national politics. That did not stop conservative intellectuals, business leaders, and Republican politicians, however, from continuously and aggressively attacking liberal policies. World War II, post-war affluence, and the climate of the Cold War gave conservatives new opportunities to regain lost influence. The civil rights movement and other conflicts that followed, along with rising inflation and other economic challenges of the late 1960s and early 1970s, among other factors, fractured the Democratic Party, and ultimately gave modern conservatism a chance to test its long-cherished public policy beliefs from a position of political dominance (Lichtman 2008; Critchlow 2007).

Reaganomics emerged as the centerpiece of the conservative program. Its combination of large regressive tax cuts, significant cuts in government programs for the poor, and a massive increase in military spending made little sense from the beginning, despite assurances from Reagan and supplyside enthusiasts that deep tax cuts would lead to more, not less, government revenue. From the moment the tax cuts went into effect, the federal deficit began to skyrocket, averaging more than 180 billion dollars per year from 1982 through 1988 and continuing to even higher levels during the presidency of Reagan's successor, George H.W. Bush. As a result, the nation's debt, measured as a percentage of GDP, began a climb of historic peacetime proportions. When Reagan assumed office, the federal debt was just under one trillion dollars, or 32.5 percent of GDP. By the time he left office, the debt was nearly 2.9 trillion dollars, or 53.1 percent of GDP. Under George H.W. Bush, the figures grew, by 1993, to 4.4 trillion in debt, or 66.2 percent of GDP. Reaganomics reversed a long trend of declining national debt that had extended from the Truman to the Carter presidencies; it transformed the United States from world's largest creditor nation into the world's largest debtor nation, keeping it, in terms of the size of its national debt, in the equivalent of a permanent wartime status (U.S. Office of Management and Budget 2008).

Having spent more than twenty years raging against government deficits, claiming in particular that they were the primary source of the inflation that had so deeply influenced the economy during the 1970s, Reagan struggled to explain all of the red ink. Initially he blamed the steep recession of 1982 and asked for time to undo the damage done by decades of liberal rule. Eventually, once high inflation rates had been knocked down by the recession, which had been caused in large part by Federal Reserve Board 
money supply policies put into effect in the Carter years, it was easier for Reagan to sidestep the issue or simply blame Congress for being unwilling to make sufficient cuts in government spending (Wilenz 2008).

Reagan and George H.W. Bush both responded to the huge deficits, in part, by agreeing to support bi-partisan bills that significantly raised taxes for working and middle-class Americans. The largest increases came in the form of gasoline taxes and Social Security payroll taxes, with minor increases in corporate taxes, income taxes in the upper brackets, and excise taxes on a number of commodities deemed to be luxuries. These tax increases stabilized Social Security's financial structure and lessened the deficits to a small extent, but they also served to reinforce the new pattern of financing American government that Reagan and the supply-siders had established: tax rates for the wealthy had been slashed and would remain low; more of the tax burden had been transferred to the middle and working classes.

The new pattern could also be seen clearly in Reagan's approach to budget cuts, government regulation, and the larger role of government in American political life. Reagan's budget cuts affected such programs as Amtrak, low-income housing, food stamps, Head Start, school lunches, CETA and other job training programs, alternative energy programs, legal aid for the poor, and other social services. Reagan, along with other conservative leaders, had long criticized Social Security and flirted with the idea of major cuts to the program, but a solid wall of opposition soon convinced Reagan not to tamper with popular middle-class entitlements. His overall cuts in the cost of federal programs, therefore, remained relatively small but tightly focused on those at the lower end of the economic spectrum.

Reagan's enthusiastic embrace of deregulation inflicted further damage on the ability of the federal government to protect the interests of ordinary citizens. Determined to go well beyond deregulation efforts in transportation and communications begun during the Carter years as a means of combating uncompetitive pricing, Reagan launched an aggressive pro-business campaign to throttle government regulation. He issued orders to halt the writing of any new rule regulating business. He slashed the budgets of regulatory agencies making it difficult for them to enforce existing rules, and he chose as leaders of the Security and Exchange Commission, the Federal Communications Commission, the Environmental Protection Agency, the Occupational Safety and Health Administration, the Department of Interior, and other key offices, individuals with records of opposition to government regulation. The results were disastrous, particularly in the areas of environment and banking. Reagan's EPA director, Anne Gorsuch Burford, compiled a dismal record of administering the Superfund program to clean up toxic waste and resigned rather than address allegations that EPA funds were 
being used primarily to help further the re-election of Republican office holders. Secretary of the Interior James Watt, who flamboyantly brandished his anti-environmental views and unapologetically opened previously protected federal lands to mining, timber, and oil interests, was also forced to resign after a series of controversies. The deregulation of the savings and loan industry brought a scandal of unprecedented proportions; bad loans and insatiable corruption led to a near collapse of the industry by 1987 with tax payers eventually paying more than $\$ 340$ billion to bail out depositors. Other major scandals involving profiteering in the Department of Housing and Urban Development and in Pentagon weapons procurement gave further evidence of Reagan's dismal record managing the federal government and protecting the public's interests (Lonley, Mayer, Shaller, and Sloan 2007; Wilentz 2008).

One of the highly significant consequences of Reagan's willingness to run up massive federal deficits and hobble government agencies could be seen in the course it set for the future of the conservative ascendancy. As the economy rebounded, oil prices dropped, and inflation remained low through the mid-1980s, Reagan's personal popularity soared and he was able to achieve a huge re-election victory in 1984. Reagan's success inspired a new generation of conservatives to pursue even more aggressive plans to slash taxes for the wealthy, escalate deregulation, and privatize government services. From the Reagan years through the turn of the century, conservative think tanks, writers, activists and political leaders surged forward with uncompromising plans to "starve the beast," to hamstring the government by keeping it burdened with debt. Well-financed conservative think tanks churned out policy papers and books trumpeting the free market and deregulation and became increasingly important centers for Republican public relations efforts (Rich 2004). Anti-tax interest groups, led by Grover Norquist's Americans for Tax Reform, began playing a pivotal role in mobilizing the conservative base and in holding up support for continuous tax cuts as a litmus test of Republican Party loyalty.

Norquist, just two years removed from his position as leader of College Republicans when he founded Americans for Tax Reform in 1985, possessed astute political and organizational skills and an extraordinarily intense ideological zeal. In 1990, when George H.W. Bush reneged on his campaign promise not to raise taxes, Norquist joined Newt Gingrich and other prominent conservative activists in renouncing Bush, claiming he had tarnished Reagan's legacy. After Bush was defeated by Bill Clinton in 1992, Norquist redoubled his efforts to insure that true anti-government conservatives controlled the Republican Party. He waged an exceedingly effective campaign to pressure every Republican candidate and office holder to sign a written anti-tax pledge. As Clinton took office, Norquist began a highly 
successful program of bringing together conservative activists, lobbyists, elected officials, and staffers at weekly strategy meetings. Held at the Americans for Tax Reform headquarters in Washington, these "Wednesday Meetings" succeeded in keeping conservative leaders motivated, organized, and unified. Despite a reputation for ideological fanaticism and inflammatory rhetoric - he once compared the estate tax to the Holocaust and declared that he wanted to get government "down to the size where we can drown it in the bathtub"-Norquist played a key role in shaping conservative policies over the next decade. He helped Newt Gingrich write the Contract with America and engineer the Republican midterm election victory in 1994, which, in turn, led to new attacks on Social Security and other entitlements, the Clinton impeachment, and other manifestations of the intense party polarization of the 1990s.

While Clinton succeeded on many levels in turning around the federal budget deficit and thwarting Republican ideologues in Congress, he was able to do so, in part, because he acknowledged the power of his adversaries and, to some degree, embraced their free market philosophy. Clinton worked with Republicans to overhaul the nation's welfare system and to pass the North American Free Trade Act, declaring in 1996 that "the era of big government is over." The economic boom of the 1990s and the zealous right-wing attempts to bring down his presidency shielded Clinton from a great deal of liberal criticism. At the same time, the now dominant forces of deregulation found ample support in both parties, leading notably to the Telecommunications Act of 1996, which spurred further consolidation in the industry, as well as the Gramm-Leach-Bliley Act of 1999, which overturned New Deal legislation separating investment banks, commercial banks, securities firms, and insurance companies. Republican Senator Phil Gramm quietly pushed through another key banking bill a year later, in the midst of the 2000 Florida election recount. This bill exempted an exotic new financial product, the credit default swap, from federal regulation.

In 2001, Norquist, Stephen Moore of the Club for Growth, and other anti-tax zealots, were at the center of the effort to pass the massive tax cuts of the George W. Bush administration (Hacker and Pierson 2007). Those tax cuts, passed in a series of bills from 2001 to 2004, were the largest of the conservative ascendancy. They totaled more than four trillion dollars over ten years, an estimated revenue loss of approximately 2.5 percent of GDP (more than three times the amount of GDP required to meet expected Social Security shortfalls during the baby boom retirement years). The first bill in 2001 was powerfully slanted toward the wealthy and set the pattern that the others would follow: 36 percent of the estimated 2.1 trillion dollar cut would go to the richest 1 percent of taxpayers; 63 percent of the cut would go to the top 20 percent; just over 20 percent of the cut would go to the bottom 
60 percent of taxpayers (Hacker and Pierson 2007). The consequences for the federal budget were the same as they had been when Reaganomics first went into effect. Under George W. Bush, budget deficits soared, reversing the budget surpluses of the Clinton years, pushing the total federal debt as a percentage of GDP from 57.4 percent in 2001 to 64.7 percent by 2006 (U.S. Office of Management and Budget 2008).

At the same time, Bush's approach to domestic policy aggressively pushed forward the conservative anti-government agenda. Just as in the Reagan years, cabinet members and other top officials in the Bush administration were chosen largely for their political loyalty and their record of opposition to activist government. Those who didn't fit the mold quickly found that they had no place inside the Bush administration. EPA director Christine Todd Whitman and Treasury Secretary Paul O'Neill were perhaps the most prominent dissenters to leave the administration. Both indicated their dismay at the administration's disdain for what they considered the basic duties of their respective offices. Others to resign included Bush's Surgeon General, Richard H. Carmona, who indicated that he was pressured to praise the President effusively in every speech and steer clear of statements about public health issues and scientific statements that did not conform to conservative ideology, and John Dilulio, a University of Pennsylvania political scientist who resigned after a short stint as director of Bush's faith-based social services initiative claiming there was no real support for the idea inside the administration (Whitman 2006; Suskind 2004; Wilentz 2008).

The Bush Justice Department scandal, which led directly to the downfall of Attorney General Alberto Gonzales and top White House political advisor Karl Rove, represented one of the egregious examples of conservative contempt for the idea of government as a public trust. After nine U.S. Attorneys were mysteriously fired in 2006, media reports, a Congressional investigation, and eventually a September 2008 report by the U.S. Inspector General's Office, indicated that the firings had been significantly influenced by partisan political considerations. Several of the U.S. Attorneys involved publicly expressed the belief that they had been fired primarily for refusing to follow the administration's wishes on prosecutions involving Democratic and Republican candidates and office holders. The refusal by Gonzales, Rove, Bush's former legal advisor and one-time Supreme Court nominee Harriet Miers, and others to cooperate with the investigation has so far kept the full extent of the scandal from being revealed. The recent decision by Gonzales's replacement, Michael Mukasey, to appoint a federal prosecutor to investigate possible criminal charges in the episode, may disclose more information (Slate, September 29, 2008; New York Times, October 1, 2008). 
Meanwhile, as the Bush administration aggressively pursued the antigovernment agenda of the conservative ascendancy, a daunting list of social and economic problems that had been created, exacerbated, or ignored during four decades of conservative political dominance loomed ever larger. The collapse of national and international financial markets in 2008, of course, was the most dramatic and obviously destructive outcome of "government is the problem" government. While the Bush administration presided over the rapid, unregulated growth of exotic new-and eventually toxic-investment products, it was merely carrying out the principals of free market fundamentalism that had been enshrined at the center of the conservative ascendancy. Throughout their reign of political dominance, nothing — not even the savings and loan industry collapse in the late 1980shad shaken conservatives' blind faith in unregulated markets. A recent admission that that faith might have been misplaced came from Alan Greenspan, the devout libertarian and Federal Reserve Chair from the last years of the Reagan administration until 2006. In October 2008, he testified in Congress that he had "found a flaw" in his life-long belief that markets could regulate themselves. "I made a mistake," he acknowledged (New York Times, October 28, 2008).

Another troubling result of the conservative anti-government agenda over the long term has been the declining economic status of middle and working class Americans. During the conservative ascendancy, economic inequality grew at a staggering rate, with income and wealth growing dramatically for the affluent while remaining stagnant for the majority at the middle and lower end of the economic spectrum. Certainly, a wide range of national and international economic forces helped account for rising economic inequality, but as Larry Bartells demonstrates in his recent authoritative work, there has nonetheless been a close relationship between rising inequality and Republican control of government. During every Republican administration of the post-World War II era, he concludes, economic circumstances improved for the wealthy more than for the middle class; during every Democratic administration, economic inequality declined (Bartels 2008).

In addition to stagnant incomes, middle and working class Americans saw steep declines in health care and education under the conservative ascendancy. By the end of the 1980s more than thirty-five million working Americans had no health insurance and those who did were entering into a period of rapidly growing costs and shrinking coverage. By the end of Bush's second term, the number of uninsured approached fifty million, costs for the insured were near back-breaking levels, the number of medical bankruptcies (almost nonexistent in other industrialized nations) reached epidemic proportions, and the great problem of funding Medicare and other 
government health care programs in the future remained unaddressed. Clinton's attempt to take on the issue during his first term was beaten back by conservative interest groups. Bush's lone accomplishment in the area of health care did substantially increase Medicare payments for prescription medicines, but did so in a way that barred the government from negotiating costs with drug companies, a plan that insured huge rewards for the pharmaceutical industry (Richmond and Fein 2005; Wilentz 2008). The continuing crisis in American education closely paralleled the situation in health care. Despite the landmark "A Nation at Risk" commission report outlining low achievement and feeble international rankings in education in 1983, the conservative ascendancy clung to solutions such as the restoration of school prayer, tax credits for private school tuition, abolishing the Department of Education, and reigning in the power of teachers' unions. Over the next twenty-five years, little progress was made in addressing the problems of underachievement in primary and secondary schools. Meanwhile, drop-out rates soared, college tuition costs skyrocketed, and economic inequality increasingly narrowed educational opportunity at every level. Bush's "No Child Left Behind” reform raised some hope for setting higher standards in public education, but was strongly criticized for making achievement tests the near total focus of school curricula, and for its failure to support the program with federal funding (Smith 2004; Sacks 2007; Dickert-Conlin and Rubenstein 2007).

\section{IV}

This essay certainly does not attempt to offer a full account of the damage done by the presidency of George W. Bush, its relationship to decades of conservative anti-government policies, or to the entire record of the conservative ascendancy. Many other important events of the last eight years in the area of domestic policy alone will surely attract the attention of scholars for years to come. Some of the more significant include the long simmering crisis of the nation's infrastructure, symbolized both by Katrina and the Minneapolis I-35 bridge collapse; the problems of energy costs and supply that have been at issue for decades and which cartwheeled with such force across the American and world economies during the second Bush term; and perhaps most critically, the global warming crisis, which decades of conservative opposition to environmental reform have made worse, and which Bush famously brushed aside with his rejection of the Kyoto Protocols. In these and other areas of politics and public policy, Bush will almost certainly be judged as a great failure as president. Indeed, he may be regarded by many to be the worst president in American history. But if he 
was the worst, his record should be measured not simply by his personal failings, but by those of the conservative ascendancy itself.

\section{REFERENCES}

Abramowitz, Alan. 2008. The Incredible Shrinking Republican Base. Real Clear Politics. http://www.realclearpolitics.com/articles/2008/05/the_incredible_shrinking_repub. $\mathrm{html}$.

Anderson, Terry H. 2005. The Pursuit of Fairness: A History of Affirmative Action. New York: Oxford University Press.

Bartels, Larry. 2008. Unequal Democracy: The Political Economy of the New Gilded Age. Princeton: Princeton University Press.

Black, Earl, and Merle Black. 2002. The Rise of Southern Republicanism. Cambridge: Harvard University Press.

Bush, George W. 2004. Press Conference Transcript. http://www.whitehouse.gov/news/ reseases/2004/11/20041104-5.html.

Bush, George W. 2005. Second Inaugural Address Transcript. http://www.whitehouse. org/news/2005/012005.asp.

Carter, Dan. 1995. The Politics of Rage: George Wallace, the Origins of the New Conservatism, and the Transformation of American Politics. New York: Simon and Schuster.

Carter, Dan. 1996. From George Wallace to Newt Gingrich: Race in the Conservative Counterrevolution, 1963-1994. Baton Rouge: Louisiana State University Press.

Crespino, Joseph. 2007. In Search of Another Country: Mississippi and the Conservative Counterrevolution. Princeton, NJ: Princeton University Press.

Critchlow, Donald T. 1999. Intended Consequences: Birth Control, Abortion, and the Federal Government in Modern America. New York: Oxford University Press.

Critchlow, Donald T. 2005. Phyllis Schlafly and Grassroots Conservatism: A Woman's Crusade. Princeton, NJ: Princeton University Press.

Critchlow, Donald T. 2007. The Conservative Ascendancy: How the GOP Right Made Political History. Cambridge, MA: Harvard University Press.

Dickert-Conlin, and Ross Rubenstein. 2007. Economics, Inequality and Higher Education: Access, Persistence and Success. New York: Russell Sage Foundation.

Dierenfeld, Bruce J. 2007. The Battle Over School Prayer: How Engle v. Vitale Changed America. Lawrence: University Press of Kansas.

Eisenberg, Jon. 2006. Using Terri: The Religious Right's Conspiracy to Take Away Our Rights. New York: HarperOne.

Formisano, Ronald P. 1991. Boston Against Busing: Race, Class and Ethnicity in the 1960s and 1970s. Chapel Hill: University of North Carolina Press.

Freeman, Steven S., and Joel Bleifuss. 2006. Was the 2004 Election Stolen?: Exit Polls, Election Fraud, and the Official Count. New York: Seven Stories Press.

Gordon, Michael R., and Bernard E. Trainor. 2006. Cobra II: The Inside Story of the Invasion and Occupation of Iraq. New York: Pantheon Books.

Hacker, Jacob S., and Pierson, Paul. 2007. Tax Politics and the Struggle over Activist Government. In The Transformation of American Politics: Activist Government and the Rise of Conservatism, eds. Paul Pierson and Theda Skocpol. Princeton, NJ: Princeton University Press. 
Horne, Jed. 2006. Breach of Faith: Hurricane Katrina and the Near Death of a Great American City. New York: Random House.

Hull, N.E.H., and Peter Charles Hoffer. 2001. Roe v. Wade: The Abortion Rights Controversy in American History. Lawrence: University Press of Kansas.

Keyssar, Alexander. 2000. The Right to Vote: The Contested History of Democracy in the United States. New York: Basic Books.

Kluger, Richard. 1976. Simple Justice: The History of Brown v. Board of Education and Black America's Struggle for Equality. New York: Knopf.

Kousser, J. Morgan. 1999. Colorblind Injustice: Minority Voting Rights and the Undoing of the Second Reconstruction. Chapel Hill: University of North Carolina Press.

Kuse, Kevin Michael. 2005. WhiteFlight: Atlanta and the Making of Modern Conservatism. Princeton, NJ: Princeton University Press.

Larson, Edward J. 2003. Trial and Error: The American Controversy Over Creation and Evolution, 3rd ed. New York: Oxford University Press.

Lassiter, Matthew D. 2006. The Silent Majority: Suburban Politics in the Sunbelt South. Princeton, NJ: Princeton University Press.

Lewis-Beck, Michael S., Helmut Norpoth, William G. Jacoby, and Herbert F. Weisberg. 2008. The American Voter Revisited. Ann Arbor: University of Michigan Press.

Lichtblau, Eric. 2008. Bush's Law: The Remaking of American Justice. New York: Pantheon.

Lichtman, Allan J. 2008. White Protestant Nation: The Rise of the American Conservative Movement. New York: Atlantic Monthly Press.

Link, William A. 2008. Righteous Warrior: Jesse Helms and the Rise of Modern Conservatism. New York: St. Martin’s Press.

Longley, Kyle, Jeremy D. Mayer, Michael Schaller, John W. Sloan. 2007. Deconstructing Reagan: Conservative Mythology and America's Fortieth President. Armonk, NY: M.E. Sharpe.

Lukas, J. Anthony. 1985. Common Ground: A Turbulent Decade in the Lives of Three Families. New York: Knopf.

Marcus, Eric. 2002. Making Gay History: The Half-Century Fight for Lesbian and Gay Equal Rights. New York: Perennial.

Mayer, Jane. 2008. Dark Side: The Inside Story of How the War on Terror Turned into a War on American Ideals. New York: Doubleday.

New York Times. November 4, 2004; September 3, 2008; October 1, 2008; October 28, 2008.

Newton, Jim. 2006. Justice For All: Earl Warren and the Nation He Made. New York: Riverhead Books.

Perlstein, Rick. 2008. Nixonland: The Rise of a President and the Fracturing of America. New York: Scribner.

Pierson, Paul, and Theda Skocpol. 2007. The Transformation of American Politics: Activist Government and the Rise of Conservatism. Princeton, NJ: Princeton University Press.

Rich, Andrew. 2004. Think Tanks, Public Policy and the Politics of Expertise. New York: Cambridge University Press.

Richmond, Julius B., and Rashi Fein. 2005. The Health Care Mess: How We Got Into It and What It Will Take To Get Out. Cambridge, MA: Harvard University Press.

Ricks, Thomas E. 2006. Fiasco: The American Military Adventure in Iraq. New York: Penguin Press.

Rimmerman, Craig A., Kenneth D. Wald, and Clyde Wilcox. 2000. The Politics of Gay Rights. Chicago: University of Chicago Press. 
Sacks, Peter. 2007. Tearing Down the Gates: Confronting the Class Divide in American Education. Berkeley: University of California Press.

Schulman, Bruce J., and Julian E. Zelizer. 2008. Rightward Bound: Making America Conservative in the 1970s. Cambridge, MA: Harvard University Press.

Slate. September 29, 2008.

Smith, Peter. 2004. The Quiet Crisis: How Higher Education is Failing America. Bolton, MA: Anker Publishing Company.

Sokol, Jason. 2006. There Goes My Everything: White Southerners in the Age of Civil Rights: 1945-1975. New York: Knopf.

Suskind, Ron. 2004. The Price of Loyalty: George W. Bush, the White House, and the Education of Paul O'Neill. New York: Simon and Schuster.

Tushnet, Mark V. 1994: Making Civil Rights Law: Thurgood Marshall and the Supreme Court, 1936-1961. New York: Oxford University Press.

Tushnet, Mark V. 1997. Making Constitutional Law: Thurgood Marshall and the Supreme Court, 1961-1991. New York: Oxford University Press.

United States Office of Management and Budget. 2006. Historical Tables, Budget of the United States, Fiscal Year 2006. http://www.whitehouse.gov/omb/budget/fy2006/ pdg/hist.pdf.

van Heerden, Ivor, and Mike Bryan. 2006. The Storm: What Went Wrong and Why During Hurricane Katrina: The Inside Story from One Louisiana Scientist. New York: Viking. Washington Post, June 29, 2007.

Whitman, Christine Todd. 2005. It's My Party Too: The Battle for the Heart of the GOP and the Future of America. New York: Penguin Press.

Wilentz, Sean. 2008. The Age of Reagan: A History, 1974-2008. New York: Harper. 